\title{
Effect of Cooking Conditions on the Flavor Formation and Adulteration Detection by Cluster Analysis of the Traditional Chinese Chicken Soup
}

\author{
Xi Feng ${ }^{1,2}$, Gang Cheng ${ }^{3}$, Xiaofeng He ${ }^{1}$, Hong Yang ${ }^{1}$, Sha Sha ${ }^{1}$ and Wen Huang ${ }^{1 *}$ \\ ${ }^{1}$ College of Food Science and Technology, China \\ ${ }^{2}$ Department of Animal Science, USA \\ ${ }^{3}$ College of Life Science, China
}

*Corresponding author: Wen Huang, College of Food Science and Technology, Wuhan, Hubei, 430070, China

$\S$ Both the authors contributed equally and both are co-first authors.

Submission: 䀝 August 15, 2017; Published: 海 October 24, 2017

\begin{abstract}
Traditional Chinese chicken soups, even have a history more than thousands of years, the mechanisms of taste formation are still unknown for us. Additionally, due to economical motivations, many restaurants use low-cost canned pressure chicken soup food adulterating as traditional Chinese chicken soups. In this study, effect of cooking conditions on water-soluble flavor, precursors and sensory properties of the traditional Chinese chicken soups was evaluated, and the qualities of traditional Chinese chicken soups (non-adulteration samples S1) and canned pressure chicken soups (adulteration samples S2) were also compared. The results indicated that prolonged heating time and lower osmotic pressure were favor to total free amino acids formation, however, overheat brought negative effect on flavor 5'-nucleotides and total carbohydrate stabilities, while the higher amount of flavor 5'-nucleotides can be easily achieved in the higher osmotic pressure conditions, and the amount of protein was more sensitive to the $\mathrm{NaCl}$ concentration. With cluster analysis, the two types of chicken soup (non-adulteration S1 and adulteration samples S2) can be divided into different clusters based on those routine physicochemical indices.
\end{abstract}

Keywords: Adulteration; Cluster analysis; Response surface methodology; Sensory evaluation; Traditional chinese chicken soup; Water-soluble flavor

Abbreviations: IMP: Inosine 5'-Monophosphate; GMP: Guanosine 5'-Monophosphate

\section{Introduction}

Traditional Chinese chicken soup (chicken soup in pottery pot) is made of Chinese native chicken with ginger, green onion, black pepper and rice wine and stewed for several hours, which is famous for its delicate processing and flavor [1]. However, due to economical motivations, many restaurants in Asian countries claim their chicken soups are made in traditional cuisine, actually they use the low cost canned pressure chicken soups instead.

In anticipation of this growing fraud problem, many analytical methods have been established to detect of the soup/broth and meat adulteration [2,3]. However, all these methods require superior instruments, and a specific component between the adulteration and non-adulteration samples.

No research has been done with the traditional Chinese chicken soup, and the mechanisms of the taste components formation related to the cooking conditions and how to detect the adulteration chicken soup is still unknown to us. The objectives of this research were to study the effect of cooking conditions on water-soluble flavor, precursors and sensory properties of chicken soup in pottery pot (traditional Chinese chicken soup) and to find the optimized levels of cooking conditions. Additionally, the sensory and physicochemical properties in chicken soup in pottery pot (non-adulteration samples) were compared with canned pressure chicken soup (adulteration samples).

\section{Material and Methods}

\section{Preparation of soup}

Sanhuang broiler, a commercial broiler; Chai-hen, a Chinese native chicken favored by the customers for the juicy texture and flavor were purchased and slaughtered immediately by exsanguinations, defeathered, manually gutted and washed with flowing tap water. The chicken meats were transported to the laboratory in insulated containers containing crushed ice and were kept at $4{ }^{\circ} \mathrm{C}$ in a refrigerator before processing.

Chicken soup in pottery pot (traditional chinese chicken soup/non-adulteration samples): Chicken thigh meat (200g) was cut into cubes $2-3 \mathrm{~cm}$ thick, blanching in boiled water for 2 minutes. After this operation, the meat was filling into a pottery pot with tap water $(500 \mathrm{ml})$. The pottery pot was heated on a silicon 
control stove ( $900 \mathrm{w}$ for $15 \mathrm{~min}$ ). When the water in the pottery pot was boiling $\left(100{ }^{\circ} \mathrm{C}\right)$, white pepper $(0.4 \mathrm{~g})$, green onion juice $(2 \mathrm{ml})$, ginger juice $(5 \mathrm{ml})$ and salt $(4 \mathrm{~g})$ was added into the water $(450 \mathrm{w}$ for $110 \mathrm{~min}$ ) [4].

Canned pressure chicken soup (adulteration samples): Chicken thigh meat sample $(70 \mathrm{~g})$ was cut into cubes $2-3 \mathrm{~cm}$ thick, tap water $(140 \mathrm{ml})$, white pepper $(0.14 \mathrm{~g})$, green onion juice $(0.7 \mathrm{ml})$, ginger juice $(1.75 \mathrm{ml})$ and salt $(1.4 \mathrm{~g})$ were filling into a tin-plated can $(65 \mathrm{~mm} \times 80 \mathrm{~mm})$ and maintained a headspace of $5 \mathrm{~mm}$. The cans were sealed with seamer and then placed in an autoclave (San-shen Medical Instrument, China) and then pressurized-cooked at 121 ${ }^{\circ} \mathrm{C}$ of the different duration $(15,20,25,30 \mathrm{~min})$. After pressurized cooking, the cans were cooled immediately [1].

\section{Experimental design}

Optimization of processing and formulation parameters of Chicken Soup in Pottery Pot was carried out using RSM [5]. The design variables were heating time in the low power (X1, min), water/chicken meat $\left(\mathrm{X}_{2}, \mathrm{~g} / \mathrm{g}\right)$, meat composition: Shanhuang broiler to Chai-hen $\left(\mathrm{X}_{3}, \mathrm{~g} / \mathrm{g}\right)$ and $\mathrm{NaCl}\left(\mathrm{X}_{4}, \%, \mathrm{~g} / \mathrm{g}, \mathrm{NaCl} /\right.$ chicken meat) while response variable was the amount of total free amino acids, flavor 5'-nucleotide, total carbohydrate, protein and sensory score of overall quality [6].

\section{Chemical analysis}

Total free amino acids were determined by ninhydrin colorimetric method [7]. Flavor 5'-nucleotides was analyzed by using the spectrophotometer method modified from Sasaki et al. [8]. Total carbohydrate was determined by phenol-sulfuric method. Protein was estimated by the method of Bradford dye-binding Nielsen [9].

\section{Sensory evaluation}

Sensory evaluation was conducted by 6 trained panelists. The tests were performed in individual booth slighted by a fluorescent white lamp. The soup samples were presented monadically for each panelist. Approximately $50 \mathrm{ml}$ of soup at a temperature of about 45 celsius degree was placed into plastic cups coded with random 3-digit numbers for identification. For each sample, panelists scored the taste, aroma, color and overall acceptance of the product. Panelists were asked to evaluate test sample at random. Tap water was used between samples to cleanse the palate [10].

\section{Statistical analysis}

The response surface regression procedure of statistical analysis system (SAS software Version 8.0.) and Design-Expert (Version 8.0.3) software were used to analyze the response surface experimental data [5]. ANOVA and cluster analysis were all performed with SAS software Version 8.0.

\section{Results and Discussion}

\section{The effect of cooking conditions on the chicken soup in pottery pot}

Total free amino acids analysis: Figure 1a indicated that the prolonged heating time and increasing SH broiler/C-henratio raised the total free amino acid $(\mathrm{P}<0.01)$. Similar results were found by Sasaki et al. [8] in the cooking juice of porcine longissimus and biceps femoris muscles. Chinese native chicken has the largest fiber density among the commercial broiler chicken and crossbred chicken's muscle, and fiber density is significantly negatively correlated with Shear force $(\mathrm{r}=-0.85, \mathrm{P}<0.001)$ [11]. Furthermore, Sasaki et al. [8] has already validated that the total free amino acid only leached from the muscles into cooking juice during wetheating cooking. Therefore, the increase in amount of total free amino acid at a higher ratio of SH broiler/C-hen might be due to a larger fiber density in C-hen muscle that facilitated a narrow space for proteinases to contact the binding site of protein hydrolyzation [12].

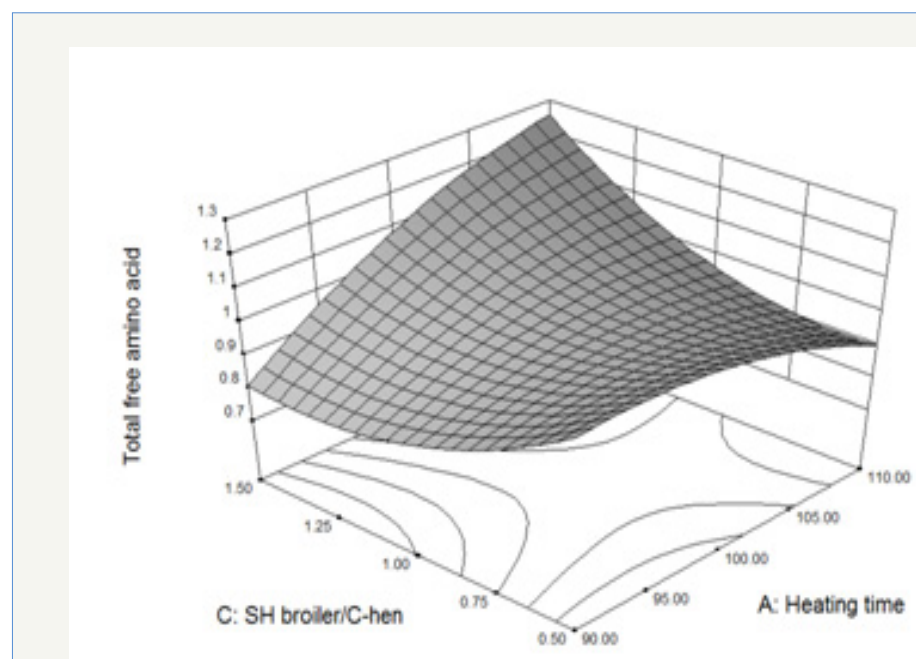

(a)

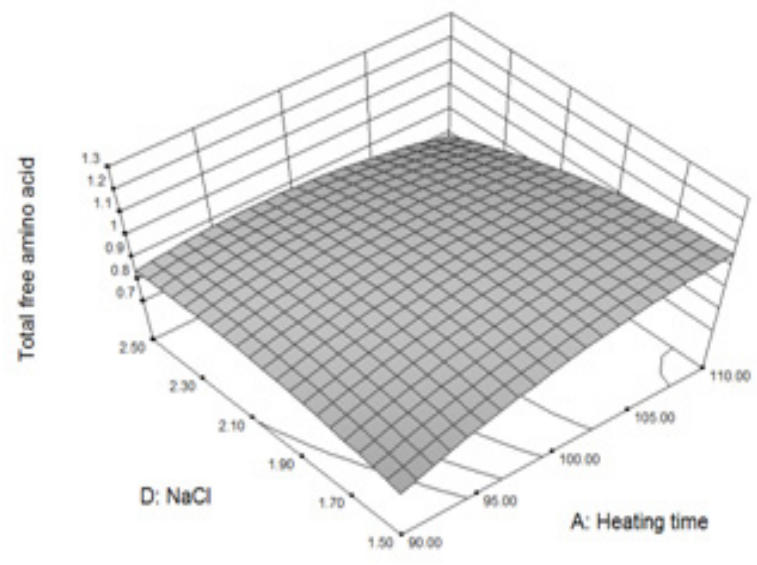

(b)

Figure 1: Response surface for the effect of the heating time and SH broiler/C-hen (a) Heating time and $\mathrm{NaCl}$ (b) On the content of total free amino acids. 
Figure $1 \mathrm{~b}$ indicated that the lower osmotic pressure of solvent increased $(\mathrm{P}<0.01)$ the total free amino acid. Similar results was found by Sasaki et al. [8], who found that wet-heat cooking of pork muscles containing $1.0 \% \mathrm{NaCl}$ had a lower amount of total free amino acid than those without $\mathrm{NaCl}$ supplementation.

Flavor 5'-nucleotides analysis: Flavor 5'-nucleotides consisted with inosine $5^{\prime}$-monophosphate (IMP) and guanosine 5'-monophosphate (GMP) [13]. Figure 2a indicated that the concentration of flavor 5'-nucleotides was increasing with the prolonging in heating time to $98 \mathrm{~min}$ and thereafter decreased with the further heating. Similar results were found by Kuehiba et al. [14], who reported that IMP and GMP were gradually degraded after long-time at elevated temperature. This observation was due to the rupture of phosphor-ester and glycosidic bonds of nucleotides [15]. The negative effect of water/chicken on the flavor 5'-nucleotides was showed in Figure $2 \mathrm{~b}$. The decrease in flavor 5'-nucleotides at a higher ratio of chicken/water could be due to dilution effect of solvent in the matrix. $\mathrm{NaCl}$ addition caused an increase in the amount of flavor 5'-nucleotides. These data indicated a high concentration of $\mathrm{NaCl}$ could prevent flavor 5'-nucleotides from thermal degradation. Kuchiba et al. [16] has also found the same effect of $\mathrm{NaCl}$ on IMP and GMP solution.

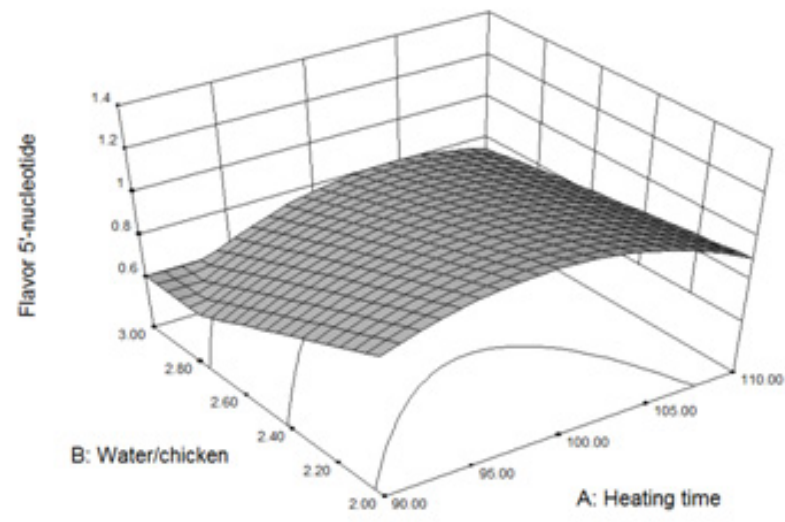

(a)

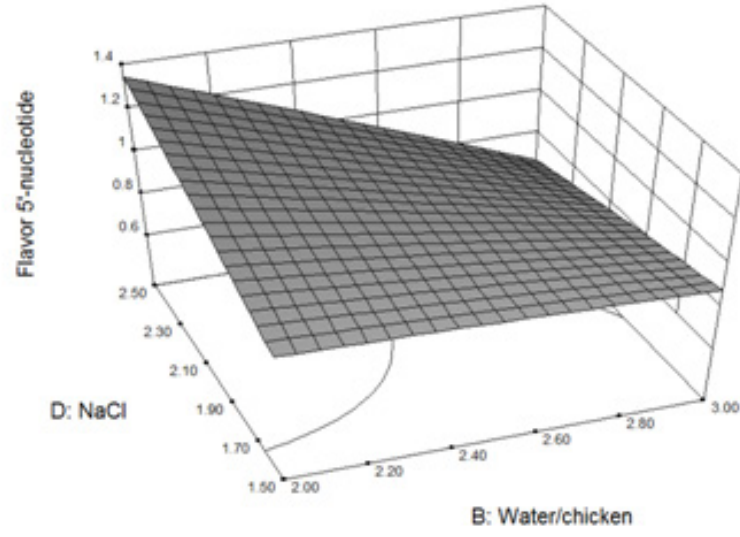

(b)

Figure 2: Response surface for the effect of the heating time and water/chicken (a) Water/Chicken and $\mathrm{NaCl}$ (b) On the content of flavor 5'-Nucleotide.
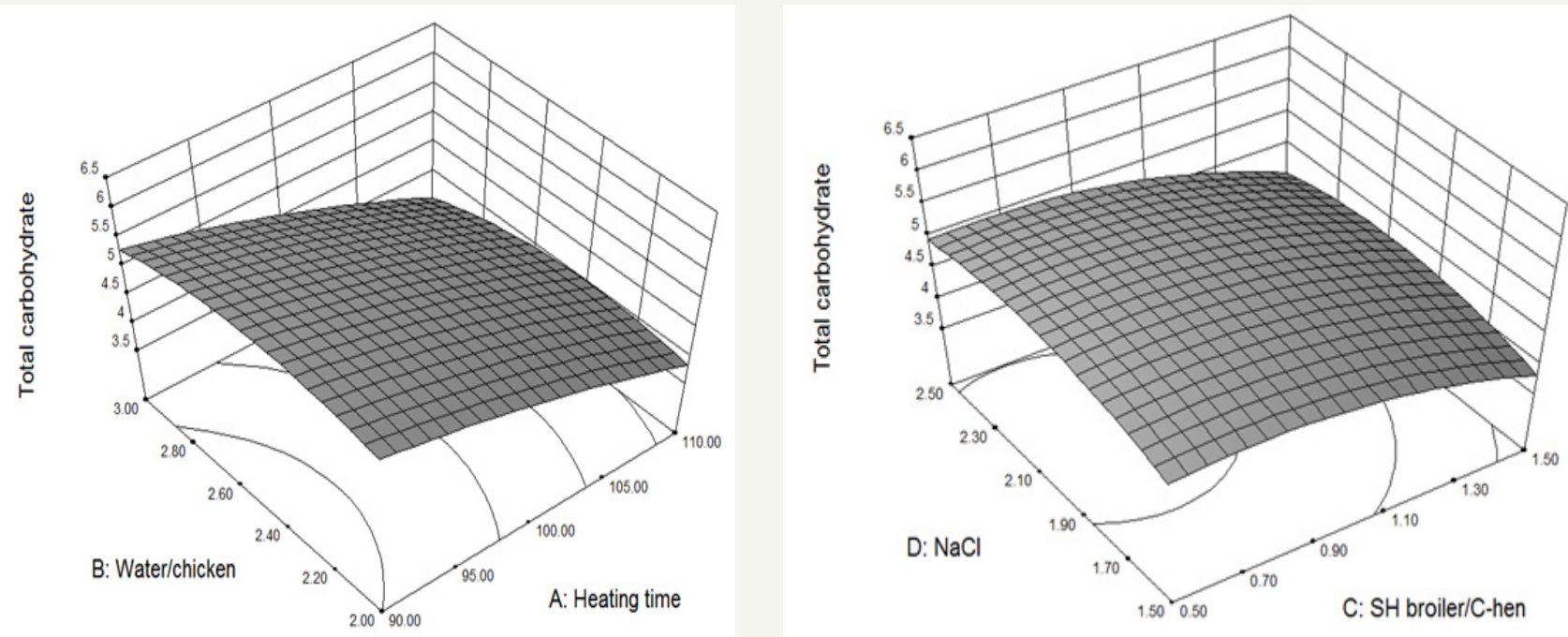

Figure 3: Response surface for the effect of the heating time and water/chicken (a) SH broiler/C-hen and $\mathrm{NaCl}$ (b) on the content of total carbohydrate.

Total carbohydrate analysis: Figure 3a showed that the amount of total carbohydrate decreased with the prolonged heating. Kuroda \& Harada [17] also observed the decrease in the levels of reducing sugar during the heating of beef soup stock. Figure $3 \mathrm{~b}$ illustrated the effect of different combinations of SH broiler/C-hen and $\mathrm{NaCl} \%$ on the amount of total carbohydrate. It was apparent that simultaneous application of a lower SH broiler/C-hen and a higher $\mathrm{NaCl}$ achieves a high amount of total carbohydrate. 
Protein Analysis: Protein was a flavor precursor, which could generate a pool of peptides and free amino acids by hydrolysis [18]. The amount of protein was dependent on $\mathrm{NaCl}$ rather than the heating time as observed in Figure $4 \mathrm{a}$. Increasing $\mathrm{NaCl}$ lead to the simultaneous increase in the amount of protein [19]. The quadratic effect of SH broiler/C-hen was as seen in Figure 4b, which showed that the amount of protein increased with SH broiler/C-hen levers to a peak and then tended to decrease as further increased.

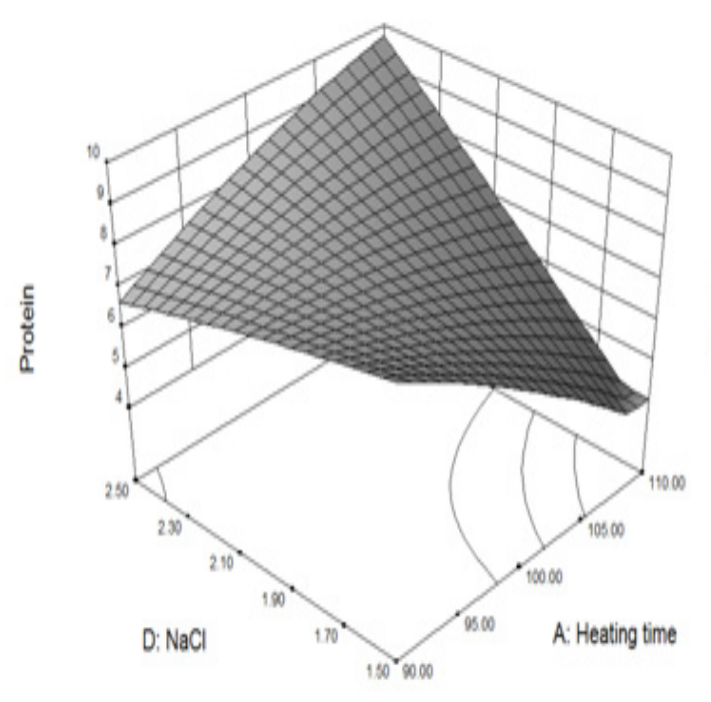

(a)

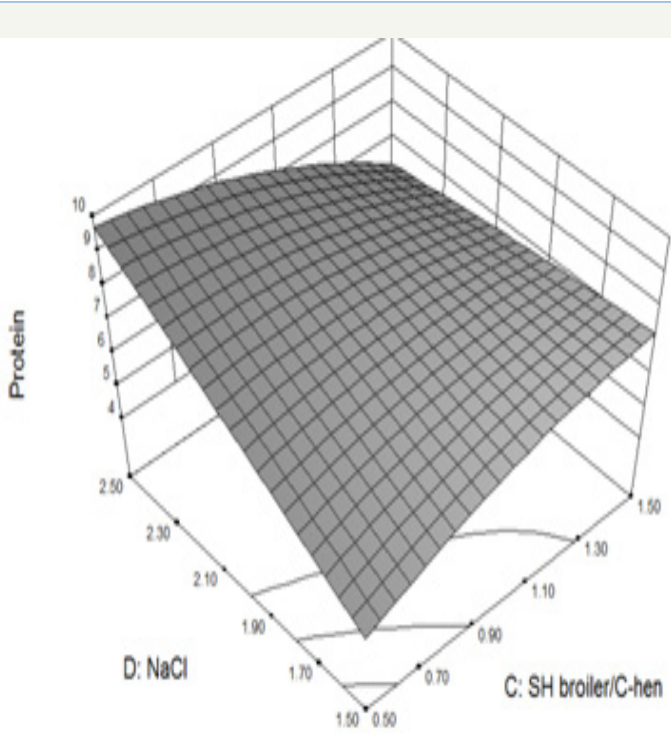

(b)

Figure 4: Response surface for the effect of the heating time and $\mathrm{NaCl}$ (a) $\mathrm{SH}$ broiler/C-hen and $\mathrm{NaCl}$ (b) on the content of protein

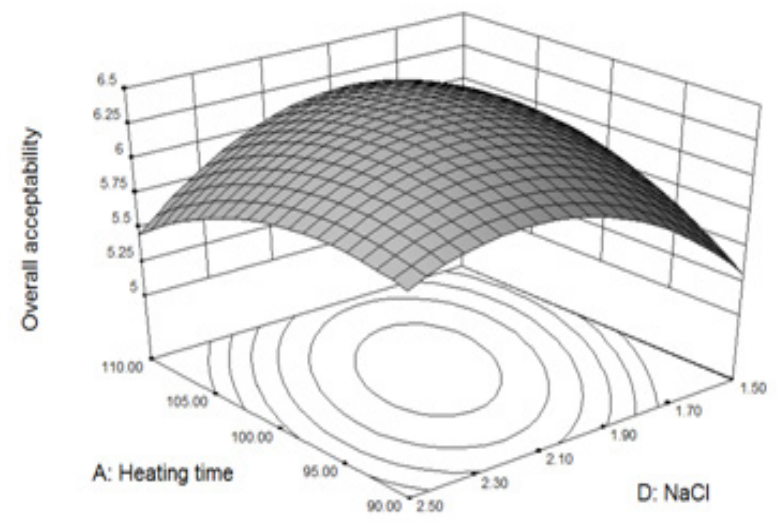

(a)

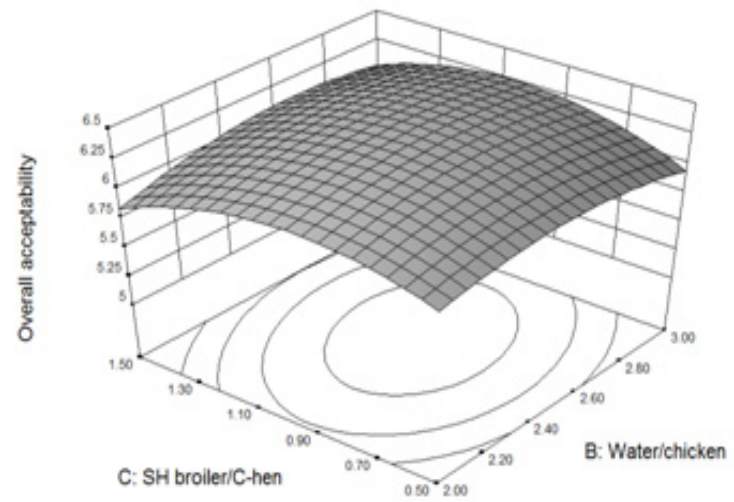

(b)

Figure 5: Response surface for the effect of the heating time and $\mathrm{NaCl}$ (a) Water/Chicken and SH broiler/C-hen (b) On the sensory score of overall acceptability.

Sensory evaluation: Figure 5a shows the overall acceptability increased with the prolonging in heating time to $101.49 \mathrm{~min}$ and $\mathrm{NaCl}$ to $2.02 \%$ and thereafter decreased with the further raise. Joseph et al. [20] also found that increasing of the end-point internal cooking temperature would bring negative effect on the flavor of the poultry meats. Figure $5 \mathrm{~b}$ showed the overall acceptability improved with the increase in water/chicken meat to 2.56 and SH broiler/C-hen to 0.99 and thereafter declined with the further raise. A relative high amount of total carbohydrate $(4.99 \mathrm{mg} / \mathrm{ml})$ was predicted at this peak, which was consistent with [21] claim: a stronger sweet taste can enhance the overall preference in the soup. Ridge analysis (Table 1) indicated that maximum sensory quality score (6.36) could be obtained. Verification experiments were performed, and taste indices demonstrated that experimental values were reasonably close to the predicted values confirming the validity and adequacy of the predicted models. 
Table 1: The results of ridge analysis.

\begin{tabular}{|c|c|c|c|c|c|c|c|c|}
\hline \multirow[b]{2}{*}{ Response } & \multirow[b]{2}{*}{ Eigen Values } & \multirow{2}{*}{$\begin{array}{l}\text { Stationary } \\
\text { Point }\end{array}$} & \multicolumn{4}{|c|}{ Experimental Factors } & \multirow[b]{2}{*}{ Maximum } & \multirow[b]{2}{*}{ Minimum } \\
\hline & & & $\begin{array}{l}\text { Heating Time } \\
\text { (Min) }\end{array}$ & $\begin{array}{c}\text { Water/ } \\
\text { Chicken (g/g) }\end{array}$ & $\begin{array}{l}\text { SH Broiler/C- } \\
\text { Hen (g/g) }\end{array}$ & $\operatorname{Nacl}(\%, g / g)$ & & \\
\hline $\begin{array}{l}\text { Free amino acids (mg/ } \\
\text { ml) }\end{array}$ & $\begin{array}{c}0.157,0.139 \\
-0.060,-0.174\end{array}$ & Saddle & $\begin{array}{l}103.89 \\
102.61\end{array}$ & $\begin{array}{c}2.85 \\
2.7\end{array}$ & $\begin{array}{l}1.19 \\
0.84\end{array}$ & $\begin{array}{l}1.78 \\
2.41\end{array}$ & 1.17 & 0.79 \\
\hline $\begin{array}{l}\text { Flavor 5'-nucleotide } \\
\qquad(\mathrm{mg} / \mathrm{ml})\end{array}$ & $\begin{array}{c}0.094,0.078 \\
-0.110,-0.204\end{array}$ & Saddle & $\begin{array}{c}98.9 \\
91.58\end{array}$ & $\begin{array}{l}2.08 \\
2.77\end{array}$ & $\begin{array}{l}0.84 \\
1.05\end{array}$ & $\begin{array}{c}2.21 \\
2\end{array}$ & 1.23 & 0.65 \\
\hline $\begin{array}{l}\text { Total carbohydrate } \\
\text { (mg/ml) }\end{array}$ & $\begin{array}{l}0.077,-0.048 \\
-0.467,-0.667\end{array}$ & Saddle & $\begin{array}{l}91.64 \\
91.58\end{array}$ & $\begin{array}{l}2.44 \\
2.77\end{array}$ & $\begin{array}{l}0.74 \\
1.05\end{array}$ & $\begin{array}{c}2.05 \\
2\end{array}$ & 6.05 & 3.89 \\
\hline Protein $(\mathrm{mg} / \mathrm{ml})$ & $\begin{array}{c}1.295,0.085 \\
-1.385,-2.262\end{array}$ & Saddle & $\begin{array}{l}102.71 \\
102.77\end{array}$ & $\begin{array}{l}2.33 \\
2.84\end{array}$ & $\begin{array}{l}0.75 \\
0.74\end{array}$ & $\begin{array}{l}2.37 \\
1.78\end{array}$ & 9.62 & 4.56 \\
\hline $\begin{array}{c}\text { Overall } \\
\text { acceptability(score) }\end{array}$ & -1.106 & Maximum & 101.71 & 2.63 & 1.03 & 2 & 6.36 & - \\
\hline
\end{tabular}

\section{Comparison of sensory and physicochemical properties} in non-adulteration and adulteration samples

Canned pressure chicken soups were acted as adulteration chicken soup samples, while chicken soups in pottery pot were used as non-adulteration ones.

Sensory evaluation: The sensory quality assessments of the chicken soup in pottery pot under optimum conditions (non- adulteration) and four different canned pressure chicken soups (adulteration) were presented in Figure 6. There were significant differences between non-adulteration and adulteration samples in the taste, aroma and overall acceptability $(\mathrm{P}<0.05)$, whileas the difference in color was not significant. The pressurized cooking time decreased $(\mathrm{P}=0.0159)$ the sensory quality of canned pressure chicken soup in overall acceptability. Similar trends were found in the sensory quality of taste, aroma and color.

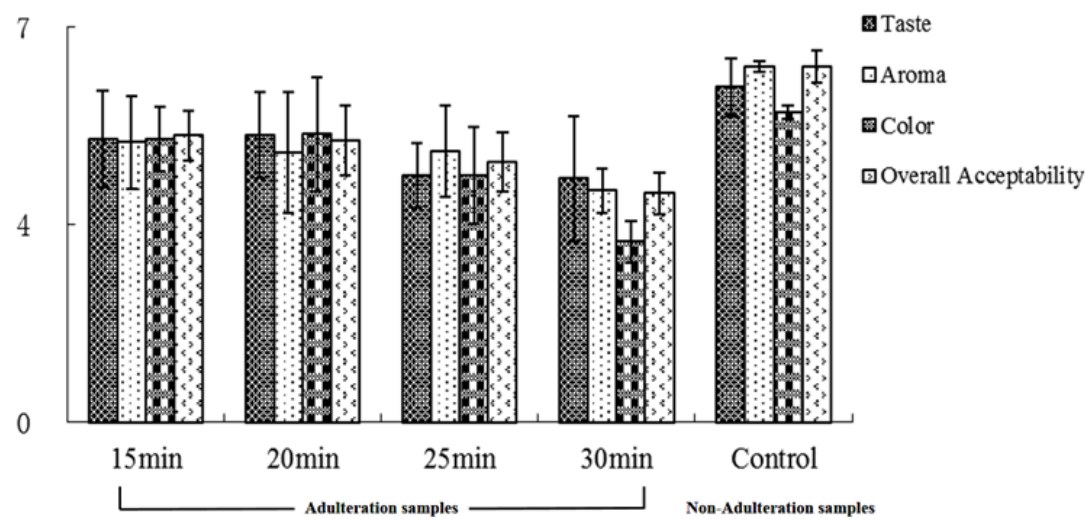

Figure 6: Comparison of sensory properties in the non-adulteration and adulteration samples.

Physicochemical properties: The physicochemical properties of the non-adulteration and adulteration chicken soups were presented in Figure 7. The non-adulteration samples exhibited a remarkably significant differences to the adulteration samples in the flavor 5'-nucleotides, total carbohydrate and protein but total free amino acids. The most remarkable difference was in the content of total carbohydrate, which was due to the sensitivity of total carbohydrate under heating [22]. Due to the unsupervised nature, cluster analysis is frequently used to group samples [23]. Figure 8 shows the dendrogram acquired by using the complete method and the squared Euclidian distance. The samples clustered into two groups: ones on the left side consisting of canned pressure chicken soups (adulteration samples); on the right side, including the chicken soups in pottery pot (non-adulteration samples). Therefore, by this method, the discrepancy of the non-adulteration and adulteration samples were discovered [24,25]. 


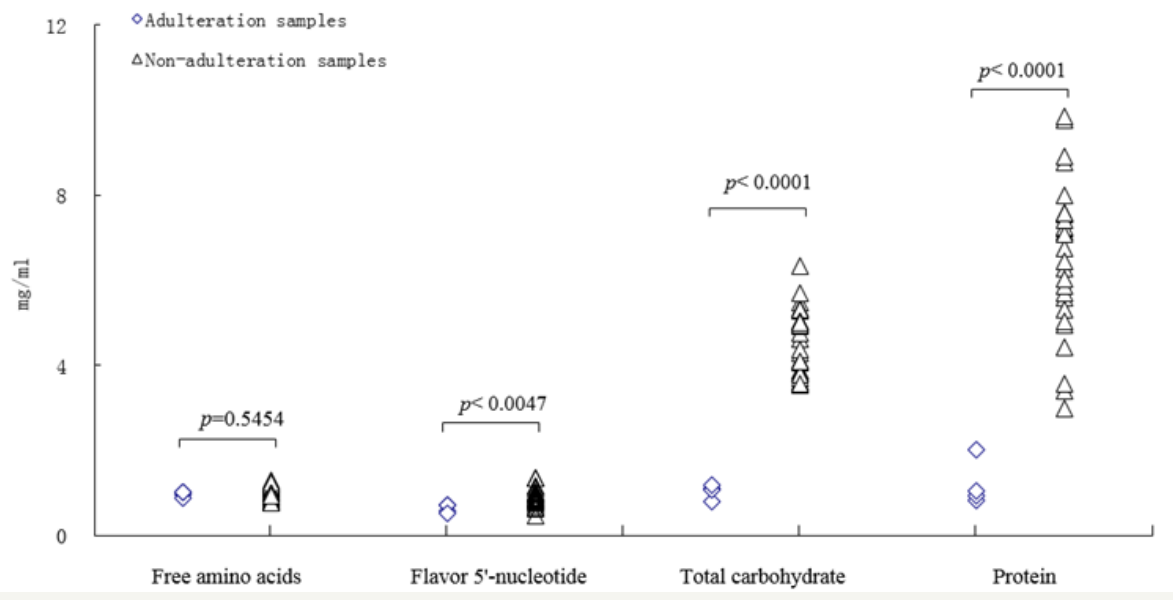

Figure 7: Comparison of physicochemical properties in the non-adulteration and adulteration samples.

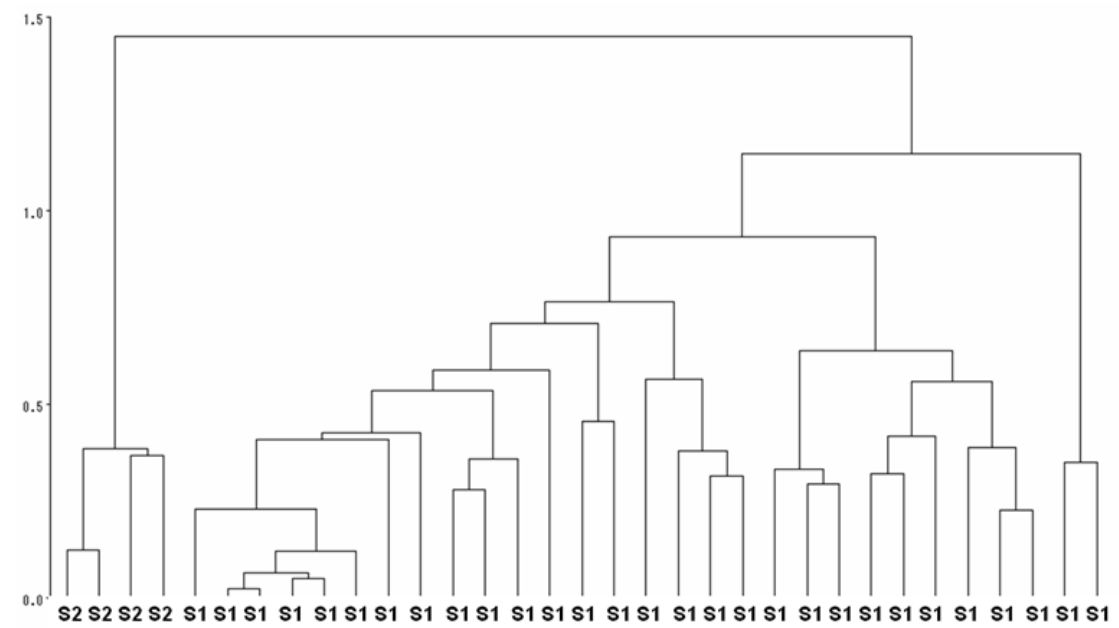

(S1: non-adulteration samples; S2: adulteration samples).

Figure 8: Dendrogram of cluster analysis.

\section{Conclusion}

The mechanism of the taste components formation related to the cooking conditions of the chicken soup in pottery pot was explored. Moreover, employing cluster analysis, adulteration and non-adulteration samples were clear divided into different two clusters based on those routine physicochemical indices instead of sensory evaluation. Therefore, the results obtained would provide useful information for the development of traditional Chinese chicken soup.

\section{Acknowledgments}

We gratefully thank Hubei Innovation Center of Agricultural Science and Technology for the financial support (Innovation Agricultural Products Research and Development Program of Hubei, P.R. China.) and this work was also kindly supported by College of Food Science and Technology, Huazhong Agricultural University, Wuhan, P.R. China.

\section{References}

1. Pin CH, Abdullah A (2009) Formulation optimization and processing parameter establishment of canned chicken in Kacangmaherbal soup. Sains Malaysiana 38(5): 665-672.

2. Nunes CA (2014) Vibrational spectroscopy and chemo metrics to assess authenticity, adulteration and intrinsic quality parameters of edible oils and fats. Food Research International 60: 255-261.

3. Zhao X, MaF, Li P, Li G, Zhang L, et al. (2015) Simultaneous determination of isoflavones and resveratrols for adulteration detection of soybean and peanut oils by mixed-mode SPE LC-MS/MS. Food Chemistry 176: 465471.

4. Yue XY (2009) Mainly taste properties and effect of processing technology on the quality of chicken soup in pottery pot [Master's thesis]. Huazhong Agricultural University 2008, Wuhan, China.

5. Myers RH, Montgomery DC (2002) Response surface methodology: process and product optimization using designed experiments $\left(2^{\text {nd }} e d n\right)$, New York, USA, pp. 1-11.

6. Liyana-PC, Shahidi F (2005) Optimization of extraction of phenolic compounds from wheat using response surface methodology. Food Chemistry 93: 47-56. 
7. McCain GR, Blumer TN, Craig HB, Steel RG (1968) Free amino acids in ham muscle during successive aging periods and their relation to flavor Journal of Food Science 33(2): 142-146.

8. Sasaki K, Motoyama M, Mitsumoto M (2007) Changes in the amounts of water-soluble umami-related substances in porcine long issimus and biceps femoris muscles during moist heat cooking. Meat Science 77(2): 167-172.

9. Nielsen SS (2003) Food analysis ( $3^{\text {rd }}$ edn), Klewer Academic/Plenum Publishers, New York, USA, 137-138, 148-149.

10. Lawless HT, Heymann H (1999) Sensory evaluation of food principles and practices. Gaithersburg, Aspen Publishers, USA, p. 827.

11. Chen XD, Ma QG, Tang MY, Ji C (2007) Development of breast muscle and meat quality in Arbor Acres broilers, Jingxing 100 crossbred chickens and Beijing fatty chickens. Meat Science 77(2): 220-227.

12.Spanier AM, McMillin KW, Miller JA (1990) Enzyme activity levels in beef: effect of postmortem aging and end-point cooking temperature. Journal of Food Sciencen 55(2): 318-322.

13.Sommer I, Schwartz H, Solar S, Sontag G (2010) Effect of gammairradiation on flavour 50-nucleotides, tyrosine, and phenylalanine in mushrooms (Agaricus bisporus). Food Chemistry 123(1): 171-174.

14. Kuehiba-MM, Matoba T, Hasegawa K (1991) Sensory changes in umami taste of inosine 5-monophosphate solution after heating. Journal of Food Science 56(5): 1429-1432.

15. Macy RL, Naumann HD, Bailey ME (1970) Water-soluble flavor and odor precursors of meat. 3. changes in nucleotides, total nusleosides and bases of beef, pork and lamb during heating. Journal of Food Science 35(1): 78-80

16. Kuchiba M, Kaizaki S, Matoba T, Hasegawat K (1990) Depressing effect of salts on thermal degradation of inosine 5-monophosphate and guanosine 5-monophosphate in aqueous solution. Journal of agricultural and food Chemistry 38(3): 593-598.

17. Kuroda M, Harada T (2000) Incorporation of histidine and $\beta$-alanine into the macromolecular fraction of beef soup stock solution. Journal of Food Science 65: 596-603.

18. Dunkel A, Hofmann T (2009) Sensory-directed identification of betaalanyl dipeptides as contributors to the thick-sour and white-meaty orosensation induced by chicken broth. Journal of Agricultural and Food Chemistry 57(21): 9867-9877.

19.Kang SY, Park KS, Choi YI, Lee SH, Auh JH, et al. (2009) Preblending effects of curing agents on the characteristics of mechanically deboned chicken meat. Korean Journal for Food Science of Animal Resources 29(2): 220-228.

20.Joseph JK, Awosanya B, Adeniran AT, Otagba UM (1997) Effects of endpoint internal cooking temperatures on the meat quality attributes of selected Nigerian poultry meats. Food quality and preference 8(1): 5761

21. Yoneda C, Okubo K, Kasai M, Hatae K (2005) Extractive components of boiled-dried scallop adductor muscle and effect on the taste of soup after mixing with chicken leg meat. Journal of the Science of Food and Agriculture 85(5): 809-816.

22. Macy RL, Naumann HD, Bailey ME (1964) Water-soluble flavor and odor precursors of meat. $\square$. Effects of heating on amino nitrogen constituents and carbohydrates in lyophilized diffusates from aqueous extracts of beef, pork, and lamb. Journal of Food Science 29: 142-148.

23.Kment P, Mihaljevic M, Ettler V, Sebek O, Strnad L, et al. (2005) Differentiation of Czech wines using multi element composition-A comparison with vineyard soil. Food Chemistry, 91: 157-165.

24. Kuroda M, Ohtake R, Suzuki E, Harada T (2000) Investigation on the formation and the determination of $\gamma$-glutamyl- $\beta$-alanylhistidine and related isopeptide in the macro molecular fraction of beef soup stock. Journal of Agricultural and Food Chemistry 48 (12): 6317-6324.

25. Ozvural EB, Vural H (2011) Grape seed flour is a viable ingredient to improve the nutritional profile and reduce lipid oxidation of frankfurters. Meat Science 88(1): 179-183. 